\title{
Involvement of the Lateral Hypothalamic Peptide Orexin in Morphine Dependence and Withdrawal
}

\author{
Dan Georgescu, ${ }^{1}$ Venetia Zachariou, ${ }^{1}$ Michel Barrot, ${ }^{1,3}$ Michihiro Mieda, ${ }^{2}$ Jon T. Willie, ${ }^{2}$ Amelia J. Eisch, ${ }^{1}$ \\ Masashi Yanagisawa, ${ }^{2}$ Eric J. Nestler, ${ }^{1}$ and Ralph J. DiLeone ${ }^{1}$ \\ ${ }^{1}$ Department of Psychiatry, and ${ }^{2}$ Department of Molecular Genetics and Howard Hughes Medical Institute, University of Texas Southwestern Medical \\ Center, Dallas, Texas 75390-9070, and ' ${ }^{3}$ nnité Mixte de Recherche 7519, Centre National de la Recherche Scientifique, University Louis Pasteur, 67084 \\ Strasbourg, France
}

\begin{abstract}
The lateral hypothalamus ( $\mathrm{LH})$ is implicated in the behavioral actions of drugs of abuse, but the cellular and molecular basis of this role is unclear. Recent identification of neuropeptides localized in LH neurons has allowed for more specific studies of LH function. The LH-specific peptide orexin (hypocretin) has been shown to be important in arousal and sleep regulation. However, orexin cells of the LH project broadly throughout the brain such that orexin may influence other behaviors as well. In this study, we show that orexin neurons, and not nearby $\mathrm{LH}$ neurons expressing melanin-concentrating hormone $(\mathrm{MCH})$, have $\mu$-opioid receptors and respond to chronic morphine administration and opiate antagonist-precipitated morphine withdrawal. cAMP response element-mediated transcription is induced in a subset of orexin cells, but not MCH cells, after exposure to chronic morphine or induction of withdrawal. Additionally, c-Fos and the orexin gene itself are induced in orexin cells in the LH during morphine withdrawal. Finally, we show that orexin knock-out mice develop attenuated morphine dependence, as indicated by a less severe antagonist-precipitated withdrawal syndrome. Together, these studies support a role for the orexin system in molecular adaptations to morphine, and demonstrate dramatic differences in molecular responses among different populations of $\mathrm{LH}$ neurons.
\end{abstract}

Key words: $\mu$-opioid receptor; CREB; c-Fos; melanin-concentrating hormone; opiate withdrawal; drug addiction

\section{Introduction}

Lesion and intracranial self-stimulation (ICSS) studies have suggested an important role for the lateral hypothalamus ( $\mathrm{LH})$ in feeding, arousal, and reward (Anand and Brobeck, 1951; Olds and Milner, 1954). Compared with other brain regions, ICSS in the LH is the most robust (Gallistel et al., 1981) and can be modulated by opiates and several other drugs of abuse or their antagonists (Adams et al., 1972; Goodall and Carey, 1975; Bozarth et al., 1980). Opiates, such as morphine, are also self-administered directly into the LH (Olds and Williams, 1980; Cazala et al., 1987). The target of these selfstimulation and self-administration studies is a subregion of the LH that is crossed by the medial forebrain bundle (MFB). Besides the passing fibers that connect limbic structures from the basal forebrain with the midbrain, the MFB also contains axons of intrinsic LH neurons (Millhouse, 1969). Moreover, previous studies have shown that ibotenic acid lesions of the LH, which destroy cell bodies but leave the passing MFB fibers intact, decrease ICSS in the LH (Velley et al., 1983). However, little is known about the specific neuronal cell types in the LH that contribute to these behaviors.

\footnotetext{
Received Dec. 18, 2002; revised Jan. 30, 2003; accepted Feb. 4, 2003.

This study was supported by grants from the National Institutes of Health to E.J.N. M.Y. is an investigator of the Howard Hughes Medical Institute. We thank Chitra Mandyam and Linda Perrotti for advice on antibody staining and Wylie Vale for the gift of anti-MCH antibody.

Correspondence should be addressed to Dr. Ralph DiLeone, Department of Psychiatry, University of Texas Southwestern Medical Center, 5323 Harry Hines Boulevard, Dallas, TX 75390-9070. E-mail: ralph.dileone@utsouthwestern.edu.

Copyright $\odot 2003$ Society for Neuroscience $\quad$ 0270-6474/03/233106-06\$15.00/0
}

Recently, several neuropeptides have been shown to be highly enriched in the LH. Two neuropeptides, orexin (also called hypocretin) and melanin-concentrating hormone $(\mathrm{MCH})$, are expressed in nonoverlapping populations of LH neurons (Peyron et al., 1998). Knock-out and transgenic overexpression studies have shown that $\mathrm{MCH}$ is important in feeding (Ludwig et al., 1998; Shimada et al., 1998), whereas orexin is important in arousal and sleep (Chemelli et al., 1999). However, there is evidence that orexin neurons may regulate other behaviors, such as stress responses (Ida et al., 2000) and feeding (Edwards et al., 1999; Haynes et al., 1999). This is consistent with the fact that orexin neurons project to many brain areas. Among these orexin projection regions are several that are implicated in behavioral responses to drugs of abuse, such as the locus ceruleus, nucleus accumbens, and ventral tegmental area (Peyron et al., 1998; Fadel and Deutch, 2002). However, little is known about the function of orexin neurons in influencing responses to drugs of abuse. In this study, we use cAMP response element (CRE) reporter mice, orexin gene reporter mice, and orexin knock-out mice to demonstrate a role for orexin in regulating morphine dependence and withdrawal.

\section{Materials and Methods}

Transgenic mouse lines. We used CRE-LacZ reporter (line 37), orexin knock-out (Impey et al., 1998), and orexin reporter (orexin- $\tau$-LacZ) mice (Chemelli et al., 1999) that had all been backcrossed more than five times to a C57BL/6 background. Animals were bred and maintained under a 12 
hr dark/light cycle with food and water available ad libitum and were used at $8-12$ weeks of age; littermates were used as controls in all experiments.

Behavioral scoring. Homozygous male orexin knock-out mice and wild-type littermates were implanted with a $25 \mathrm{mg}$ morphine base pellet subcutaneously, or received sham surgery (no pellet), under light isofluorane anesthesia. Two days later, mice received naloxone ( $1 \mathrm{mg} / \mathrm{kg}$, s.c.), and withdrawal symptoms (jumps, wet dog shakes, backwards walking, paw tremor, tremor, diarrhea, ptosis, and weight loss) were monitored for $25 \mathrm{~min}$ (Shaw-Lutchman et al., 2002). A global withdrawal score was calculated by multiplying withdrawal signs by a constant and adding the scores for each sign. A separate set of mice was exposed to an open field, and activity and locomotion were recorded for $3 \mathrm{hr}$ before the onset of the dark cycle.

Immunohistochemical studies. Orexin- $\tau$-LacZ and CRE-LacZ mice were implanted subcutaneously on day 1 with a $25 \mathrm{mg}$ morphine pellet or received sham surgery. An identical procedure was performed on day 3 . On day 6, mice received saline or naltrexone $(100 \mathrm{mg} / \mathrm{kg}$, s.c.), a dose required for maximal, sustained levels of withdrawal (Shaw-Lutchman et al., 2002). Four hours later (to permit reporter gene expression), animals were injected with an overdose of pentobarbital and perfused transcardially with $1 \times$ PBS followed by $4 \%$ paraformaldehyde. The brains were postfixed for $12 \mathrm{hr}$ in $4 \%$ paraformaldehyde and then cryoprotected in $20 \%$ glycerol for $6 \mathrm{hr}$. Brains were sectioned at $40 \mu \mathrm{m}$ intervals and collected in $1 \times$ PBS plus $0.05 \%$ sodium azide.

Double-labeling immunohistochemistry was performed as described previously (Shaw-Lutchman et al., 2002) using goat polyclonal anti- $\beta$ galactosidase ( $\beta$-gal) antibody (1:5000; Biogenesis, Poole, UK), rabbit polyclonal anti-orexin antibody (1:400; Chemicon, Temecula, CA), rabbit polyclonal anti-MCH antibody (1:5000; gift from W. Vale, Salk Institute, La Jolla, CA), goat polyclonal anti-c-Fos antibody (1:500; Santa Cruz Biotechnology, Santa Cruz, CA), goat polyclonal anti-FosB antibody (1:500; Santa Cruz Biotechnology), or rabbit polyclonal anti- $\mu$ opioid receptor (anti-MOR; 1:4000; ImmunoStar, Hudson, WI). Quantification and localization of $\beta$-gal, c-Fos, or FosB expression with orexin or $\mathrm{MCH}$ were performed using fluorescent light microscopy by an investigator blinded to treatment conditions.

Triple-labeling immunocytochemistry used mouse anti-orexin (1:500; R\&D Systems, Minneapolis, MN), goat anti-c-Fos (1:500) or goat anti- $\beta$-gal (1:5000), and rabbit anti- $\mu$-opioid receptor (1:4000). Secondary antibodies were added sequentially: first, the $\mathrm{Cy}-2$ donkey anti-goat (1:200) and Cy-5 donkey anti-mouse antibodies in $1 \times$ PBS for $4 \mathrm{hr}$, followed by biotinylated goat anti-rabbit antibody $(1: 400)$ in $1 \times$ PBS for $1 \mathrm{hr}$. An avidin-biotin complex $(\mathrm{ABC})$ reaction (Vectastain Elite kit; Vector Laboratories, Burlingame, CA) was performed for $10 \mathrm{~min}$ followed by a 10 min tyramide signal amplification (TSA Plus Fluorescence Systems kit; PerkinElmer Life Sciences, Boston, MA). Each of the four components of the amplification reaction was omitted as a control. Analysis of triple-labeling was performed by confocal microscopy (LSM 510; Zeiss, Oberkochen, Germany) at $630 \times$ magnification. Sections were optically sliced in the $z$-plane at $0.4 \mu \mathrm{m}$ intervals.

Analysis of $\beta$-gal expression. Perfused brains of orexin- $\tau$-LacZ mice were cut as $40 \mu \mathrm{m}$ coronal sections, and 5-bromo-4-chloro-3-indolyl- $\beta$ D-galactopyranoside histochemistry was performed as described previously (Min et al., 1994). For quantification, images of brain sections were captured at $200 \times$ magnification, and densitometry was performed on anteroposteriorly matched sections using NIH Image software, as described previously (Min et al., 1996). For every mouse used (six per group), the density of all cell bodies (5-15 per section) from three adjacent, anatomically matched sections was measured and averaged.

Statistical analysis. Results were expressed as mean \pm SEM. Statistical significance was estimated using the $t$ test or one-way ANOVA followed by the Tukey post hoc test when appropriate. A $p$ value of $<0.05$ was considered significant.

\section{Results}

\section{Orexin neurons are regulated by chronic morphine and morphine withdrawal}

To better understand the effects of morphine on the LH, we evaluated molecular responses to chronic morphine and mor- phine withdrawal precipitated by the opioid receptor antagonist naltrexone. CRE-LacZ transgenic mice were used as a reporter of CRE-mediated transcription (Impey et al., 1998), which is known to be regulated by morphine in several other brain regions (ShawLutchman et al., 2002). In these mice, the LacZ gene is induced with activation of CRE-binding protein (CREB) or a CREB family protein (Montminy et al., 1990; Sheng et al., 1990; Van Nguyen et al., 1990). We used double-labeling immunohistochemistry to colocalize CRE activity (i.e., LacZ expression) with orexin or $\mathrm{MCH}$ neurons. Chronic administration of morphine caused an $\sim 10$-fold induction of CRE activity in orexin cells (Fig. $1 A, B)\left(F_{(3,23)}=49.93 ; p<0.05\right)$. Precipitation of withdrawal tended to produce a larger induction of CRE activity, although this was not statistically significant. Naltrexone by itself, in morphine-naive animals, produced a much smaller induction of CRE activity in orexin neurons (Fig. $1 C, D$ ). Under all three experimental conditions (chronic morphine, morphine withdrawal, or naltrexone alone), there was virtually no induction seen in $\mathrm{MCH}$ neurons (Fig. $1 A, B$ ). This is in contrast to the selective activation of CRE-LacZ in MCH neurons after starvation (data not shown), indicating that the CRE-LacZ reporter can be activated in both cell types. Interestingly, only a subset of orexin cells showed responses to morphine: $25 \%$ of orexin cells were activated after chronic morphine and 33\% during withdrawal (Fig. $1 B$ ). Moreover, orexin neurons accounted for only approximately one-half of the $\beta$-gal-positive neurons observed, indicating that induction of CRE activity also occurs in a population of orexin-negative and $\mathrm{MCH}$-negative neurons.

As a second measure of response to morphine treatments, we studied the induction of c-Fos in wild-type C57BL/6 mice. c-Fos induction has been used as a marker of neuronal activation during opiate withdrawal (Hayward et al., 1990; Georges et al., 2000; Gracy et al., 2001). Whereas chronic morphine treatment, or naltrexone administration to morphine-naive animals, did not induce c-Fos in orexin or MCH cells, precipitation of morphine withdrawal significantly induced c-Fos immunoreactivity in orexin cells, with no response seen in $\mathrm{MCH}$ cells (Fig. 1C,D) $\left(F_{(3,20)}=15.79 ; p<0.05\right)$. Levels of the Fos family protein FosB, which is also induced by morphine treatments in some brain regions (Nye and Nestler, 1996), were also analyzed. However, we found very little induction of FosB in the $\mathrm{LH}$, with no induction seen in orexin or MCH cells (data not shown).

\section{Morphine withdrawal induces orexin gene expression}

To assess the impact of chronic morphine and precipitated withdrawal on orexin gene expression, we used a new line of orexin$\tau$-LacZ reporter mice, where the $\tau$-LacZ cassette was knocked into the endogenous orexin locus. The fusion between $\beta$-gal and $\tau$ in these mice makes it possible to visualize neuronal processes in addition to cell bodies. As an initial test of the reporter, one group of mice was deprived of food for $24 \mathrm{hr}$, and a control group had normal access to food. Food restriction induced a robust increase in the density of LacZ staining in the LH compared with controls (data not shown). Similar increases in orexin mRNA levels have been demonstrated in the LH with food deprivation (Sakurai et al., 1998; Cai et al., 1999; Lopez et al., 2000), indicating that regulation of the reporter gene follows the normal pattern of orexin expression. We subsequently examined the effect of chronic morphine and morphine withdrawal on different groups of orexin- $\tau$-LacZ mice. No change in LacZ staining was detected in response to chronic morphine or to naltrexone in morphinenaive mice (Fig. 2). However, precipitation of morphine withdrawal caused a 56\% increase in LacZ staining $\left(F_{(3,19)}=5.78 ; p<\right.$ 
A

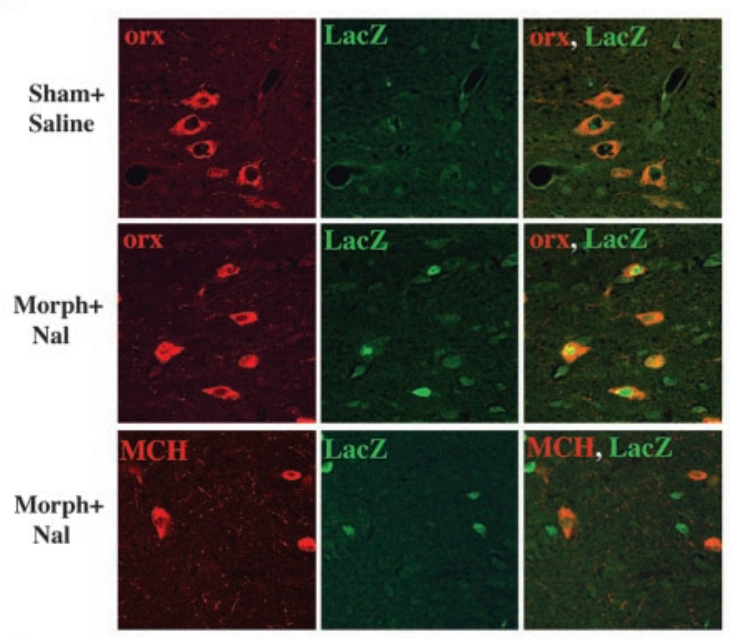

B

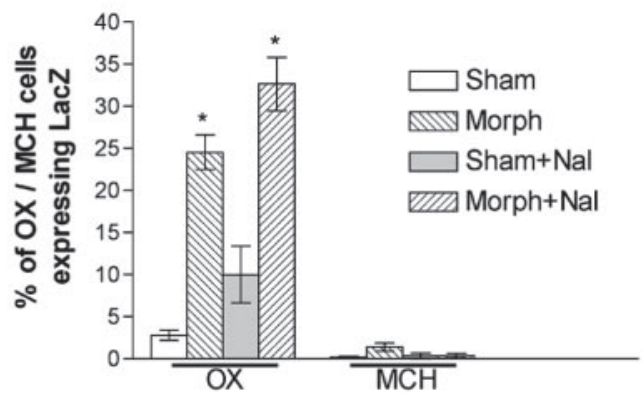

C

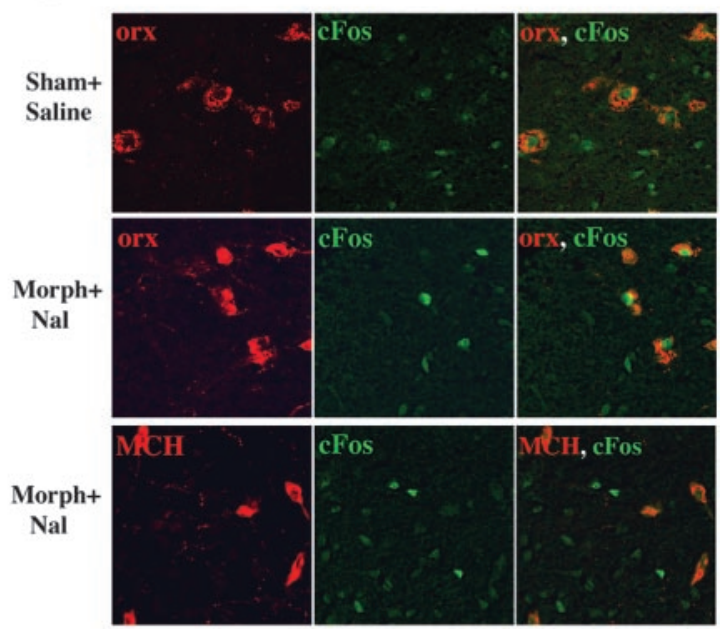

D

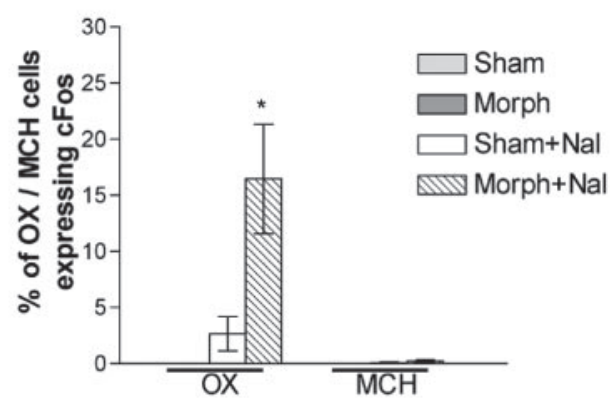

Figure 1. Chronic morphine (Morph) and withdrawal selectively affect orexin (OX) neurons. Confocal microscopy shows double-label immunohistochemistry for orexin or MCH with $\beta$-gal ( $A$ ) or $c$-Fos ( $C$ ). The data were quantified and summarized for CRE-LacZ ( $B)$ and for $c-$ Fos ( $D)\left(n=6\right.$ per group). Nal, Naltrexone. ${ }^{*} p<0.05$.

0.01). The increase in LacZ staining during withdrawal was particularly apparent in cellular processes, which demonstrates the utility of the $\tau$-LacZ reporter.

\section{Morphine-responsive orexin neurons express the $\boldsymbol{\mu}$-opioid receptor}

To investigate the possibility of a direct effect of morphine on orexin cells, we used double-labeling immunofluorescence to examine the presence of MORs on orexin cells in the LH. Examination by conventional and confocal microscopy revealed that $\sim 50 \%$ of orexin cells display high levels of MOR immunoreactivity. Because only a subset of orexin cells respond with CRELacZ or c-Fos activation, we performed confocal analysis on triple-immunostained LH sections from animals during precipitated withdrawal. This analysis confirmed that all orexin cells that respond with CRE-LacZ or c-Fos also express MORs, suggesting a direct mode of action. In addition, nonorexin cells that express CRE-LacZ or c-Fos also express MORs (Fig. 3).

\section{Orexin knock-out mice display attenuated morphine withdrawal}

The above molecular studies indicated that orexin neurons and the orexin gene are regulated by morphine treatment. To investigate the possible behavioral significance of this regulation, we studied morphine withdrawal in orexin knock-out mice. Precipitation of withdrawal in wild-type littermates induced classic behavioral signs of withdrawal (Fig. 4). Several but not all of these signs were markedly attenuated in the orexin knock-outs, and the overall withdrawal score was significantly decreased (wild-type
A
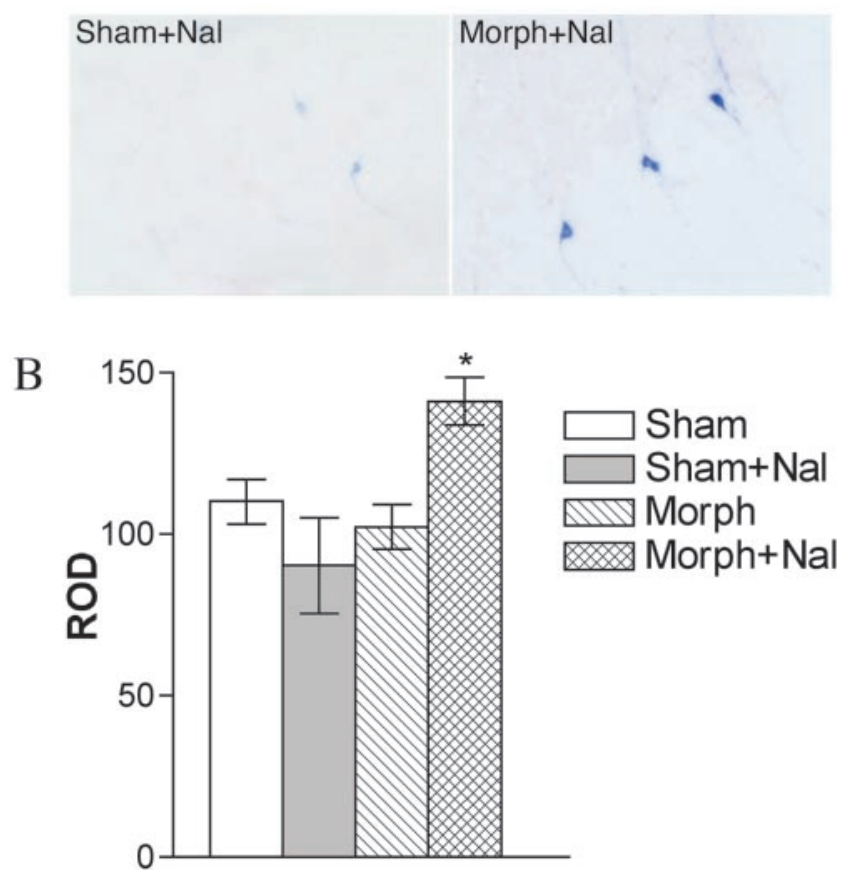

Figure 2. Withdrawal induces orexin gene expression in orexin- $\tau$-LacZ mice. $A, A$ representative image showing $\beta$-gal staining in the $\mathrm{LH}$ after sham plus naltrexone (Nal; left) or morphine (Morph) plus naltrexone (right). $B$, Mean optical densities are indicated ( $n=5$ per group). ROD, Relative optical density. 

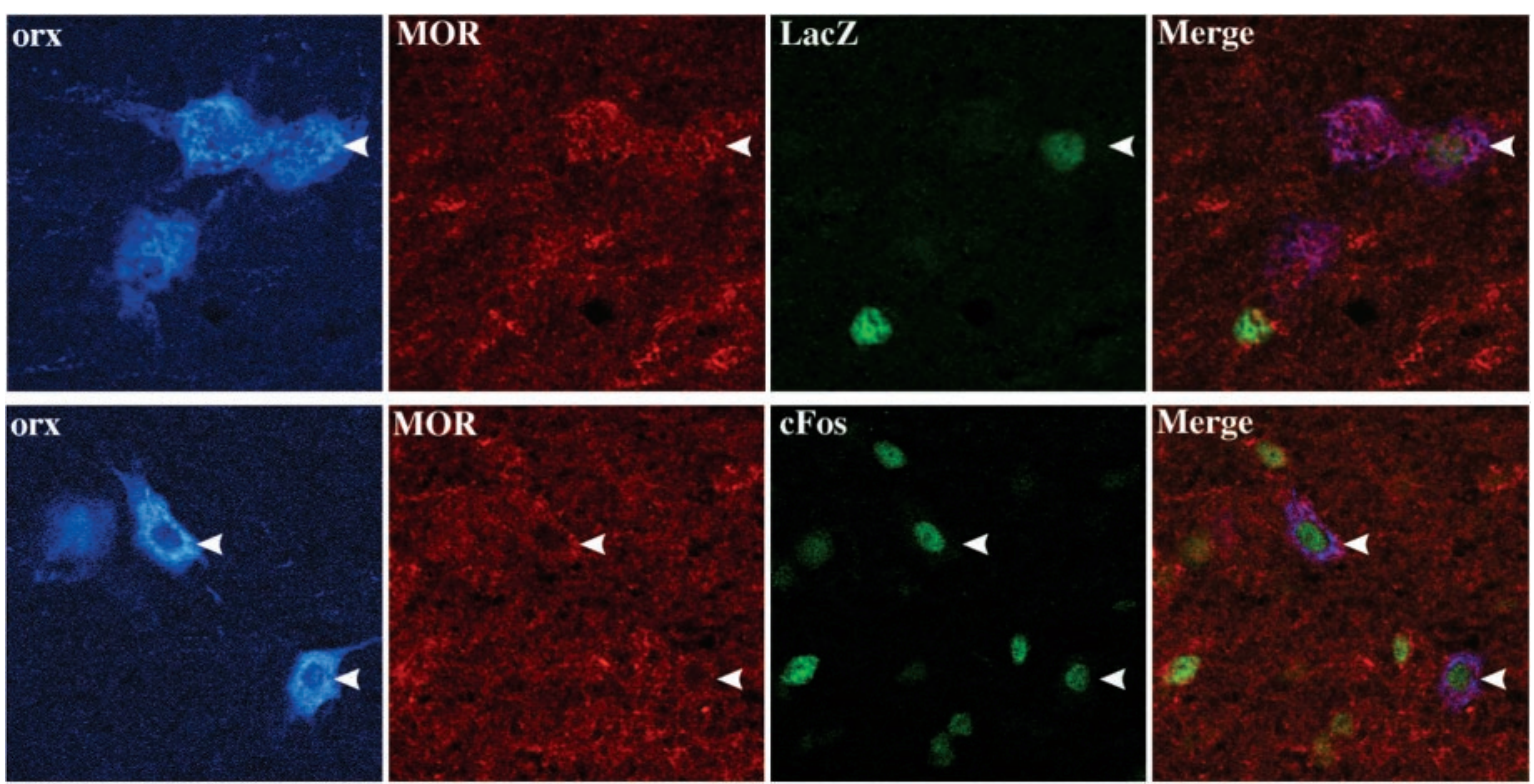

Figure 3. Triple immunostaining showing orexin (orx) cells expressing MOR and LacZ (top) or c-Fos (bottom) as responses to morphine withdrawal. Arrowheads indicate triple positive staining shown on the far right (Merge). Also present are nonorexin cells showing LacZ or c-Fos.

mice, $99.44 \pm$ 15.76; knock-out mice, $42.02 \pm 5.38$; $p<0.05 ; n=$ 8 per group). In contrast, orexin mutant mice showed normal open-field locomotor activity (Fig. 4G,H) and stereotypy (data not shown), and no other general behavioral abnormalities were observed.

\section{Discussion}

Previous ICSS and self-administration studies support the involvement of the LH in behavioral responses to morphine and other opiates (Bozarth et al., 1980; Gallistel et al., 1981). Regions of LH that support morphine self-administration correspond to optimal ICSS sites, which are located in the MFB, a bundle of fibers that connects mesencephalic regions (e.g., the ventral tegmental area) with forebrain structures (e.g., the nucleus accumbens). Although the fibers are known to be important for ICSS, cells intrinsic to the $\mathrm{LH}$ also seem to be involved (Velley et al., 1983). The studies reported here are the first to directly implicate orexin neurons in morphine action. Interestingly, endogenous opioids are needed for orexin-induced feeding (Clegg et al., 2002), suggesting multiple points of interaction between orexin and opioids.

Using CRE-LacZ reporter mice, we demonstrate induction of CRE-mediated transcription in the LH by chronic morphine administration, with no additional activation observed during precipitation of withdrawal. A significant fraction of this induction occurs in orexin neurons, whereas virtually no induction is seen in $\mathrm{MCH}$ neurons. The fact that CRE activity is seen in the chronic morphine-treated state, without induction of withdrawal, suggests that morphine exposure is sufficient to induce molecular changes that may reflect neural plasticity in response to drug exposure. We also examined induction of c-Fos by chronic morphine and precipitated withdrawal. In contrast to CRE activity, c-Fos was not induced by chronic morphine but was robustly induced during withdrawal. This response, like the induction of CRE activity, was seen in orexin cells but not in MCH cells. These findings suggest that morphine withdrawal produces acute activation of orexin cells. In addition to these changes in transcription factors, morphine withdrawal also induced the orexin gene
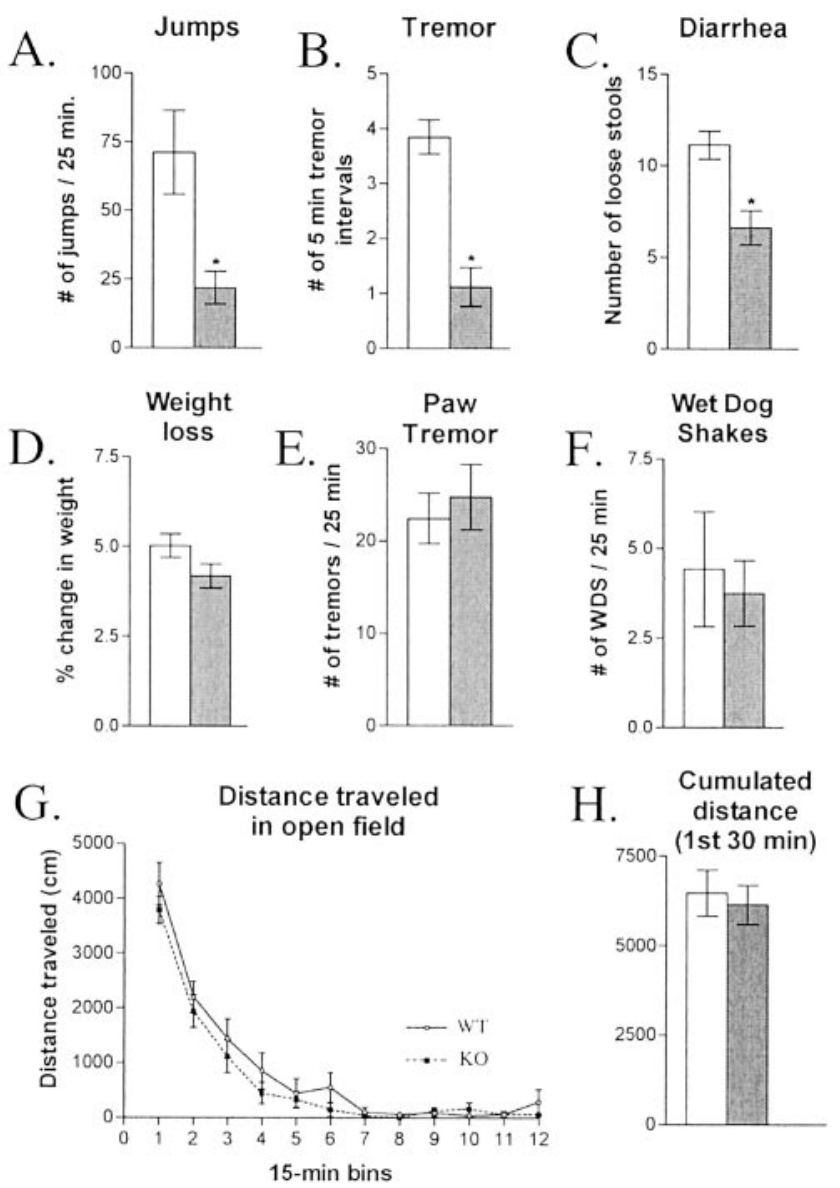

Figure 4. Morphine withdrawal is attenuated in orexin knock-out mice. Orexin knock-outs (gray bars) are compared with their wild-type littermates (white bars) for jumps $(A)$, tremor $(B)$, diarrhea $(C)$, weight loss $(D)$, paw tremor $(E)$, and wet dog shakes (WDS; $F)\left(n=8\right.$; ${ }^{*} p<$ $0.01)$. Open-field locomotor time course $(G)$ and cumulative distance for the first $30 \mathrm{~min}$ in a separate set of animals $(H)$ are also shown. ACSF, Artificial CSF. 
itself, as seen in orexin- $\tau$-LacZ reporter mice. Together, these studies demonstrate the regulation of orexin cells by chronic morphine and morphine withdrawal. However, it is important to note that orexin neurons account for only a portion of cells in the $\mathrm{LH}$ that show induction of CRE activity and c-Fos in response to chronic morphine or morphine withdrawal. Identification of the other cell types will help to delineate the heterogeneous neuronal populations found in the LH.

The attenuation of morphine withdrawal seen in orexin knock-out mice implies that the orexin system serves an important functional role in modulating responses to morphine. The broad projections of orexin neurons and their potential interactions with dopaminergic systems (Nakamura et al., 2000), adrenergic systems (Hagan et al., 1999; Horvath et al., 1999; Bourgin et al., 2000), and the hypothalamic-pituitary-adrenal axis (Kuru et al., 2000) suggest that multiple modes of action may be implicated in orexin modulation of morphine withdrawal. Although orexin knock-out mice also display narcolepsy and cataplexy, we did not observe sleep attacks during the 25 min testing period, and locomotor activity was normal. This is expected, because we performed these studies during the light phase, when sleep attacks are infrequent (Chemelli et al., 1999).

Although MORs have been detected previously in the LH (Mansour et al., 1987; Delfs et al., 1994; Mansour et al., 1994; Briski and Sylvester, 2001), the cellular identity of these neurons was unknown. We show in this study that a subset $(\sim 50 \%)$ of orexin neurons expresses MORs, and that most of these cells respond to morphine by induction of CRE activity or c-Fos. The data also suggest, not surprisingly, that orexin cells are not a homogeneous population. Indeed, it has been demonstrated that amphetamine and antipsychotic drugs induce c-Fos in subsets of orexin neurons (Fadel et al., 2002). It is notable that all cells, both orexin and nonorexin, that show molecular responses to morphine express MORs.

The induction of CRE activity and c-Fos in orexin cells that express the MOR suggests that regulation of the cells by chronic morphine and morphine withdrawal is mediated via direct actions of morphine on these cells. Chronic morphine upregulates the cAMP pathway in many regions of the central and peripheral nervous systems, where it has been shown to be an important mechanism underlying opiate dependence and withdrawal (Nestler, 2001). The expression of MORs on orexin neurons and the activation of CRE-mediated transcription in these cells after chronic morphine treatment suggest that a similar upregulation of the cAMP pathway may occur in these LH neurons. Although additional work is needed to identify the target genes of the cAMP cascade in orexin neurons, the orexin gene itself does not appear to be one of them, because chronic morphine did not increase orexin gene expression in the orexin- $\tau$-LacZ reporter mice. It is also notable that orexin cells express the endogenous opioid peptide dynorphin (Chou et al., 2001); it remains to be determined whether this colocalization has functional implications for mechanisms of morphine withdrawal.

The data presented in this study begin to define, on a molecular and cellular level, the relationship between the LH and drug addiction. Multiple lines of evidence implicate orexin neurons in behavioral responses to morphine. Specifically, induction of c-Fos suggests that orexin neurons are activated during precipitated morphine withdrawal, with the induction of orexin gene expression possibly representing a response to restore orexin levels after a period of increased neural activity. The attenuated withdrawal syndrome seen in orexin knock-out mice suggests that such regulation of orexin neurons may be an important con- tributor to morphine physical dependence and to the expression of withdrawal. Additional studies are now needed to assess a role for the orexin system in other behavioral actions of morphine, in particular those actions related to ICSS and self-administration.

\section{References}

Adams WJ, Lorens SA, Mitchell CL (1972) Morphine enhances lateral hypothalamic self-stimulation in the rat. Proc Soc Exp Biol Med 140:770-771.

Anand BK, Brobeck JR (1951) Hypothalamic control of food intake in rats and cats. Yale J Biol Med 24:123-140.

Bourgin P, Huitron-Resendiz S, Spier AD, Fabre V, Morte B, Criado JR, Sutcliffe JG, Henriksen SJ, de Lecea L (2000) Hypocretin-1 modulates rapid eye movement sleep through activation of locus ceruleus neurons. J Neurosci 20:7760-7765.

Bozarth MA, Gerber GJ, Wise RA (1980) Intracranial self-stimulation as a technique to study the reward properties of drugs of abuse. Pharmacol Biochem Behav 13:245-247.

Briski KP, Sylvester PW (2001) Co-distribution of Fos- and mu opioid receptor immunoreactivity within the rat septopreoptic area and hypothalamus during acute glucose deprivation: effects of the mu receptor antagonist CTOP. Neurosci Lett 306:141-144.

Cai XJ, Widdowson PS, Harrold J, Wilson S, Buckingham RE, Arch JR, Tadayyon M, Clapham JC, Wilding J, Williams G (1999) Hypothalamic orexin expression: modulation by blood glucose and feeding. Diabetes 48:2132-2137.

Cazala P, Darracq C, Saint-Marc M (1987) Self-administration of morphine into the lateral hypothalamus in the mouse. Brain Res 416:283-288.

Chemelli RM, Willie JT, Sinton CM, Elmquist JK, Scammell T, Lee C, Richardson JA, Williams SC, Xiong Y, Kisanuki Y, Fitch TE, Nakazato M, Hammer RE, Saper CB, Yanagisawa M (1999) Narcolepsy in orexin knockout mice: molecular genetics of sleep regulation. Cell 98:437-451.

Chou TC, Lee CE, Lu J, Elmquist JK, Hara J, Willie JT, Beuckmann CT, Chemelli RM, Sakurai T, Yanagisawa M, Saper CB, Scammell TE (2001) Orexin (hypocretin) neurons contain dynorphin. J Neurosci 21:RC168(1-6).

Clegg DJ, Air EL, Woods SC, Seeley RJ (2002) Eating elicited by orexin-A, but not melanin-concentrating hormone, is opioid mediated. Endocrinology 143:2995-3000.

Delfs JM, Kong H, Mestek A, Chen Y, Yu L, Reisine T, Chesselet MF (1994) Expression of mu opioid receptor mRNA in rat brain: an in situ hybridization study at the single cell level. J Comp Neurol 345:46-68.

Edwards CM, Abusnana S, Sunter D, Murphy KG, Ghatei MA, Bloom SR (1999) The effect of the orexins on food intake: comparison with neuropeptide $\mathrm{Y}$, melanin-concentrating hormone and galanin. J Endocrinol 160:R7-R12.

Fadel J, Deutch AY (2002) Anatomical substrates of orexin-dopamine interactions: lateral hypothalamic projections to the ventral tegmental area. Neuroscience 111:379-387.

Fadel J, Bubser M, Deutch AY (2002) Differential activation of orexin neurons by antipsychotic drugs associated with weight gain. J Neurosci 22:6742-6746.

Gallistel CR, Shizgal P, Yeomans JS (1981) A portrait of the substrate for self-stimulation. Psychol Rev 88:228-273.

Georges F, Stinus L, Le Moine C (2000) Mapping of $c$-fos gene expression in the brain during morphine dependence and precipitated withdrawal, and phenotypic identification of the striatal neurons involved. Eur J Neurosci 12:4475-4486.

Goodall EB, Carey RJ (1975) Effects of D- versus L-amphetamine, food deprivation, and current intensity on self-stimulation of the lateral hypothalamus, substantia nigra, and medial frontal cortex of the rat. J Comp Physiol Psychol 89:1029-1045.

Gracy KN, Dankiewicz LA, Koob GF (2001) Opiate withdrawal-induced fos immunoreactivity in the rat extended amygdala parallels the development of conditioned place aversion. Neuropsychopharmacology 24:152-160.

Hagan JJ, Leslie RA, Patel S, Evans ML, Wattam TA, Holmes S, Benham CD, Taylor SG, Routledge C, Hemmati P, Munton RP, Ashmeade TE, Shah AS, Hatcher JP, Hatcher PD, Jones DN, Smith MI, Piper DC, Hunter AJ, Porter RA, et al. (1999) Orexin A activates locus coeruleus cell firing and increases arousal in the rat. Proc Natl Acad Sci USA 96:10911-10916.

Haynes AC, Jackson B, Overend P, Buckingham RE, Wilson S, Tadayyon M, Arch JR (1999) Effects of single and chronic intracerebroventricular administration of the orexins on feeding in the rat. Peptides 20:1099-1105. Hayward MD, Duman RS, Nestler EJ (1990) Induction of the c-fos proto- 
oncogene during opiate withdrawal in the locus coeruleus and other regions of rat brain. Brain Res 525:256-266.

Horvath TL, Peyron C, Diano S, Ivanov A, Aston-Jones G, Kilduff TS, van Den Pol AN (1999) Hypocretin (orexin) activation and synaptic innervation of the locus coeruleus noradrenergic system. J Comp Neurol 415:145-159.

Ida T, Nakahara K, Murakami T, Hanada R, Nakazato M, Murakami N (2000) Possible involvement of orexin in the stress reaction in rats. Biochem Biophys Res Commun 270:318-323.

Impey S, Smith DM, Obrietan K, Donahue R, Wade C, Storm DR (1998) Stimulation of cAMP response element (CRE)-mediated transcription during contextual learning. Nat Neurosci 1:595-601.

Kuru M, Ueta Y, Serino R, Nakazato M, Yamamoto Y, Shibuya I, Yamashita H (2000) Centrally administered orexin/hypocretin activates HPA axis in rats. NeuroReport 11:1977-1980.

Lopez M, Seoane L, Garcia MC, Lago F, Casanueva FF, Senaris R, Dieguez C (2000) Leptin regulation of prepro-orexin and orexin receptor mRNA levels in the hypothalamus. Biochem Biophys Res Commun 269:41-45.

Ludwig DS, Mountjoy KG, Tatro JB, Gillette JA, Frederich RC, Flier JS, Maratos-Flier E (1998) Melanin-concentrating hormone: a functional melanocortin antagonist in the hypothalamus. Am J Physiol 274:E627-E633.

Mansour A, Khachaturian H, Lewis ME, Akil H, Watson SJ (1987) Autoradiographic differentiation of $\mu, \delta$, and $\kappa$ opioid receptors in the rat forebrain and midbrain. J Neurosci 7:2445-2464.

Mansour A, Fox CA, Thompson RC, Akil H, Watson SJ (1994) mu-Opioid receptor mRNA expression in the rat CNS: comparison to mu-receptor binding. Brain Res 643:245-265.

Millhouse OE (1969) A Golgi study of the descending medial forebrain bundle. Brain Res 15:341-363.

Min N, Joh TH, Kim KS, Peng C, Son JH (1994) 5' Upstream DNA sequence of the rat tyrosine hydroxylase gene directs high-level and tissue-specific expression to catecholaminergic neurons in the central nervous system of transgenic mice. Brain Res Mol Brain Res 27:281-289.

Min N, Joh TH, Corp ES, Baker H, Cubells JF, Son JH (1996) A transgenic mouse model to study transsynaptic regulation of tyrosine hydroxylase gene expression. J Neurochem 67:11-18.

Montminy MR, Gonzalez GA, Yamamoto KK (1990) Regulation of cAMPinducible genes by CREB. Trends Neurosci 13:184-188.

Nakamura T, Uramura K, Nambu T, Yada T, Goto K, Yanagisawa M, Sakurai
T (2000) Orexin-induced hyperlocomotion and stereotypy are mediated by the dopaminergic system. Brain Res 873:181-187.

Nestler EJ (2001) Molecular basis of long-term plasticity underlying addiction. Nat Rev Neurosci 2:119-128.

Nye HE, Nestler EJ (1996) Induction of chronic Fos-related antigens in rat brain by chronic morphine administration. Mol Pharmacol 49:636-645.

Olds J, Milner P (1954) Positive reinforcement produced by electrical stimulation of septal area and other regions of rat brain. J Comp Physio Psychol 47:419-427.

Olds ME, Williams KN (1980) Self-administration of D-Ala2-Metenkephalinamide at hypothalamic self-stimulation sites. Brain Res 194:155-170.

Peyron C, Tighe DK, van den Pol AN, de Lecea L, Heller HC, Sutcliffe JG, Kilduff TS (1998) Neurons containing hypocretin (orexin) project to multiple neuronal systems. J Neurosci 18:9996-10015.

Sakurai T, Amemiya A, Ishii M, Matsuzaki I, Chemelli RM, Tanaka H, Williams SC, Richardson JA, Kozlowski GP, Wilson S, Arch JR, Buckingham RE, Haynes AC, Carr SA, Annan RS, McNulty DE, Liu WS, Terrett JA, Elshourbagy NA, Bergsma DJ, et al. (1998) Orexins and orexin receptors: a family of hypothalamic neuropeptides and $\mathrm{G}$ protein-coupled receptors that regulate feeding behavior. Cell 92:573-585.

Shaw-Lutchman TZ, Barrot M, Wallace T, Gilden L, Zachariou V, Impey S, Duman RS, Storm D, Nestler EJ (2002) Regional and cellular mapping of cAMP response element-mediated transcription during naltrexoneprecipitated morphine withdrawal. J Neurosci 22:3663-3672.

Sheng M, McFadden G, Greenberg ME (1990) Membrane depolarization and calcium induce $c$-fos transcription via phosphorylation of transcription factor CREB. Neuron 4:571-582.

Shimada M, Tritos NA, Lowell BB, Flier JS, Maratos-Flier E (1998) Mice lacking melanin-concentrating hormone are hypophagic and lean. $\mathrm{Na}$ ture 396:670-674.

Van Nguyen T, Kobierski L, Comb M, Hyman SE (1990) The effect of depolarization on expression of the human proenkephalin gene is synergistic with cAMP and dependent upon a cAMP-inducible enhancer. J Neurosci 10:2825-2833.

Velley L, Chaminade C, Roy MT, Kempf E, Cardo B (1983) Intrinsic neurons are involved in lateral hypothalamic self-stimulation. Brain Res 268: 79-86. 